\title{
Surface disinfection of Atlantic halibut Hippoglossus hippoglossus eggs with ozonated sea-water inactivates nodavirus and increases survival of the larvae
}

\author{
Sindre Grotmol ${ }^{1, *}$, Geir K. Totland ${ }^{2}$ \\ 'Department of Aquaculture, Institute of Marine Research, PO Box 1870 Nordnes, 5024 Bergen, Norway \\ ${ }^{2}$ Department of Zoology, University of Bergen, Allégt. 41, 5007 Bergen, Norway
}

\begin{abstract}
Disinfection by ozonation of sea-water may reduce the risk of transmission of nodavirus, a major fish pathogen, via Atlantic halibut Hippoglossus hippoglossus eggs. In the present study, eggs at $4 \mathrm{~d}$ prior to hatching were exposed to nodavirus and then to ozonated sea-water using different concentrations $\left(0.3\right.$ to $\left.10 \mathrm{mg} \mathrm{l}^{-1}\right)$ and exposure times $(0.5$ to $10 \mathrm{~min})$. None of the larvae from virus-exposed eggs washed with ozonated sea-water developed viral encephalopathy and retinopathy (VER), which was detected in all dead larvae from eggs exposed to nodavirus but not washed with ozonated seawater. In the non-treated control group about $20 \%$ of the dead larvae developed the disease. This suggests that the halibut eggs taken from a large-scale production facility were already contaminated with nodavirus. The egg groups which had been treated with $4 \mathrm{mg} \mathrm{O}_{3} \mathrm{I}^{-1}$ for $0.5 \mathrm{~min}$ or with lower total ozone exposures had a higher survival and no adverse effects on the development of the larvae after hatching were observed. Although a slight delay in hatching was found, after $2 \mathrm{~d}$ the cumulative hatching had normalised. In the egg groups with high total exposure $\left(4 \mathrm{mg} \mathrm{O} \mathrm{O}^{-1}\right.$ for $1 \mathrm{~min}$ or higher total ozone exposures) a pronounced negative effect on hatching was observed. Our results indicate that the egg surface may be important in the transfer of nodavirus and that nodavirus associated with the surface of the egg may be inactivated by ozonated sea-water.
\end{abstract}

KEY WORDS: Atlantic halibut · Fish egg - Ozonation - Egg disinfection - Aquaculture techniques . Nodavirus · Atlantic halibut · Viral encephalopathy and retinopathy (VER)

\section{INTRODUCTION}

In farming of the Atlantic halibut Hippoglossus hippoglossus, a major obstacle for the aquaculture industry has been the predictable production of juveniles. Infectious diseases are important factors that influence survival in intensive aquaculture, and measures to control disease are essential for high, stable production. Furthermore, interregional trade in live fish and eggs provides a potential for the parallel movement of pathogens. Egg disinfection is thus an important barrier to the geographical spread of disease

·E-mail: sindre.grotmol@imr.no and to the transfer of pathogens between broodstock and their offspring. In addition to egg disinfection, other hygienic measures in the production of juveniles ought to include stringent control of water quality and other potential routes of disease transmission such as feed, equipment and personnel.

Nodaviruses are non-enveloped with icosahedral capsids (diameter 25 to $40 \mathrm{~nm}$ ), and their genome consists of 2 single-stranded messenger sense RNA molecules, the RNA1 and the RNA2 (Mori et al. 1992, Comps et al. 1994). They are neuropathogenic in fish and cause disease with high mortality in the larvae of at least 20 cultured marine teleosts in different parts of the world (Munday \& Nakai 1997, Song et al. 1997) The disease is characterised by vacuolation of the 
central nervous system (CNS) and the retina, and has been referred to as fish encephalitis (Breuil et al. 1991), viral nervous necrosis (VNN) (Yoshikoshi \& Inuoe 1990) and viral encephalopathy and retinopathy (VER) (Munday et al. 1992). Mortality caused by nodavirus is a significant problem in Atlantic halibut farming (Grotmol et al. 1997).

In addition to horizontal transmission (Munday \& Nakai 1997), vertical transmission of nodavirus has been demonstrated in striped jack Pseudocaranx dentex (Arimoto et al. 1992, Mushiake et al. 1994) and has been indicated in European sea bass Dicentrarchus labrax (Comps et al. 1996), Japanese flounder Paralichthys olivaceus and barfin flounder Verasper moseri (Yoshimizu et al. 1997). Persistently infected broodstock are thus thought to be a major reservoir of nodavirus, transmitting the virus to their offspring through virus shed into their gonadal fluids. At present, conclusive information concerning the routes of nodavirus transmission in Atlantic halibut farming is lacking. In spawning Atlantic halibut, nodavirus could not be detected in the gonadal fluids by reverse transcriptase polymerase chain reaction (RT-PCR) (Grotmol unpubl data), suggesting that vertical transmission in this species is less probable. It cannot be ruled out, however, that nodavirus may be present in gonadal fluids of the Atlantic halibut in numbers below the detection limit of the RT-PCR, a phenomenon sometimes observed in spawning striped jack (Nishizawa et al. 1996). Although the mechanisms of nodavirus transfer in the Atlantic halibut are not understood, egg disinfection may reduce the probability of vertical transmission of nodavirus or other pathogens if present in broodstock. If such disinfection is to be meaningful, the water supply to the production facility should also be disinfected to ensure that horizontal contamination with nodavirus or other pathogens does not occur.

The effects of disinfectants such as iodophores, chloramine, hypochlorite and glutaraldehyde have previously been studied on Atlantic halibut eggs (Harboe et al. 1994, Salvesen \& Vadstein 1995, Bergh \& Jelmert 1996), but their anti-viral effects have not been evaluated. Nodaviruses are stable and thus viable after treatment with several disinfectants (Arimoto et al. 1996, Frerichs \& Tweedie 1997). Washing eggs with ozonated sea-water, however, efficiently inactivated striped jack nervous necrosis virus (SJNNV) (Arimoto et al. 1996). Side effects of treating eggs with ozonated sea-water may be delay of hatching and reduced hatching rate (Arimoto et al. 1996, Mimura et al. 1998).

When ozone is introduced into sea-water, a number of oxidants are formed. These compounds, i.e. bromates, which are hazardous to fish, particularly the early life stages (Hall et al. 1981), may be stable for days or weeks (Yoshimizu et al. 1995). Our study was designed to reveal the nodavirucidal and toxic effects of ozonated sea-water in the surface disinfection of Atlantic halibut eggs.

\section{MATERIALS AND METHODS}

Eggs. Eggs and sperm were obtained by stripping 1 female and 1 male of the wild-caught broodstock at Austevoll Aquaculture Research Station (Norway). The fertilisation rate was approximately $95 \%$. Before transfer to the laboratory at 60.5 degree-days, the eggs were reared at $6^{\circ} \mathrm{C}$ in a $250 \mathrm{l}$ upwelling egg incubator for $10 \mathrm{~d}$ (Pittman et al. 1990). Nodavirus was not detected in the gonadal fluids of the spawners employing RT-PCR according to Nishizawa et al. (1994).

Preparation of infectious material and exposure of the eggs to nodavirus. Atlantic halibut larvae and juveniles infected with nodavirus were collected during episodes of acute high mortality in a commercial hatchery. The specimens were stored frozen at $-80^{\circ} \mathrm{C}$. Histopathological and electron microscopic examinations of the larvae revealed vacuolating encephalopathy and retinopathy associated with a nodavirus-like agent as described by Grotmol et al. (1997). The infectivity of the material had previously been tested on Atlantic halibut larvae (Grotmol et al. 1999). An infectious homogenate was prepared according to the following procedure: $2 \mathrm{~g}$ of tissue, consisting of the eyes, crania and vertebral columns were homogenised in a $10 \mathrm{ml}$ Potter-Elvehjems tissue grinder with $10 \mathrm{ml}$ sterile $0.9 \% \mathrm{NaCl}(\mathrm{aq})$. The homogenate was cleared by centrifugation at $3000 \times g$ for $20 \mathrm{~min}$ at $4^{\circ} \mathrm{C}$, and the supernatant was filtered through a membrane with a pore size of $220 \mathrm{~nm}$.

The presence of nodavirus in the homogenate was tested for by RT-PCR (Nishizawa et al. 1994) and a single product of 426 base pairs (T4 region) was generated. To test for the presence of infectious pancreatic necrosis virus (IPNV), cultures of Chinook salmon embryo cells (CHSE-214) were inoculated with the homogenates and no cytopathic effect was observed after 2 passages.

Before exposure to nodavirus, 1 group of 60 eggs was transferred to a beaker for use as a non-treated control group ( $\mathrm{Gr} \mathrm{NC}$ ). The remaining eggs were exposed by gently stirring $20 \mathrm{ml}$ of the infectious homogenate into a 21 bucket. The eggs were incubated with the virus for $30 \mathrm{~min}$, strained and transferred to autoclaved, diluted sea-water of $25 \%$ salinity. For the different ozone treatments, 16 groups, each consisting of 60 eggs, were transferred to separate beakers. A further group of 60 eggs was transferred to a beaker for use as an experimentally virus-exposed, non-ozonated control group (Gr EC). 
Ozone treatment and rearing conditions. Ozonation of sea-water: Sea-water (80 l) was held in a reaction chamber connected to a circulation pump. Ozone gas, produced by an ozone generator (PK Ozone A/S, Molde, Norway), was mixed with the sea-water using a gas injector connected to the sea-water circulation system. The temperature of the sea-water was kept at $6^{\circ} \mathrm{C}$.

Measurement of oxidative power expressed as $\mathbf{m g}$ $\mathrm{O}_{3} \mathrm{I}^{-1}$ : The oxidative power of the ozonated sea-water was measured by iodometry according to the method of the American Public Health Association (Franson [ed] 1989). According to this method the oxidative power is expressed as $\mathrm{mg} \mathrm{Cl}_{2} \mathrm{l}^{-1}$. In this study the oxidative power was expressed in $\mathrm{mg} \mathrm{O}_{3} \mathrm{l}^{-1}$ by means of the following formula: $\mathrm{mg} \mathrm{O}_{3} \mathrm{l}^{-1}=0.68 \mathrm{mg} \mathrm{Cl}_{2} \mathrm{l}^{-1}$

Egg disinfection: Disinfection was performed within $3 \mathrm{~h}$ after virus exposure. Each of the 16 egg groups were treated with 1 of 4 ozone concentrations $(0.3,1,4$ or $10 \mathrm{mg} \mathrm{O}_{3} \mathrm{l}^{-1}$ ), in combination with one of 4 exposure times $(0.5,1,3$ and $5 \mathrm{~min}$ ) (Table 1$)$. In addition, 1 virusexposed group was not subjected to ozonated seawater (Gr EC), and 1 group was neither experimentally exposed to virus nor subjected to ozonated sea-water ( $\mathrm{Gr}$ NC). Each group consisted of 60 eggs.

Rearing conditions: The eggs and larvae were kept in complete darkness in a climate-regulated room at $6^{\circ} \mathrm{C}$ except during periods of rearing and observation, when the room was illuminated by a dim red light (2.5 lx). The eggs and larvae were incubated in polystyrene 6-well tissue-culture plates (Multidish 6, Nunc, Roskilde, Denmark). The wells had a diameter of $35 \mathrm{~mm}$ and a depth of $18 \mathrm{~mm}$. The wells were filled with $10 \mathrm{ml}$ autoclaved, diluted sea-water (25\% salinity), which had been temperature equilibrated to $6^{\circ} \mathrm{C}$. Each of the 60 eggs from each of the experimental groups were transferred to a separate well.

Day 0 was defined as the day on which at least $50 \%$ of the eggs in the non-treated control group (Gr NC) had hatched. On the day after hatching, $9 \mathrm{ml}$ of water was removed from each well together with the eggshell debris and replaced with fresh autoclaved diluted sea-water ( $25 \%$ salinity).

Table 1. Experimental groups classified by the ozone concentration and exposure time. In addition, 1 experimentally virusexposed egg group not exposed to ozonated sea-water (Gr EC) and 1 group neither experimentally exposed to nodavirus nor to ozonated sea-water ( $\mathrm{Gr} \mathrm{NC}$ ) were kept as controls. Gr: group

\begin{tabular}{|lllll|}
\hline & $0.3 \mathrm{mg} \mathrm{O}_{3} \mathrm{l}^{-1}$ & $1 \mathrm{mg} \mathrm{O}_{3} \mathrm{l}^{-1}$ & $4 \mathrm{mg} \mathrm{O}_{3} \mathrm{l}^{-1}$ & $10 \mathrm{mg} \mathrm{O}_{3} \mathrm{l}^{-1}$ \\
\hline $0.5 \mathrm{~min}$ & $\mathrm{Gr} 0.3 / 0.5$ & $\mathrm{Gr} 1 / 0.5$ & $\mathrm{Gr} 4 / 0.5$ & $\mathrm{Gr} \mathrm{10/0.5}$ \\
$1 \mathrm{~min}$ & $\mathrm{Gr} 0.3 / 1$ & $\mathrm{Gr} 1 / 1$ & $\mathrm{Gr} 4 / 1$ & $\mathrm{Gr} 10 / 1$ \\
$3 \mathrm{~min}$ & $\mathrm{Gr} 0.3 / 3$ & $\mathrm{Gr} 1 / 3$ & $\mathrm{Gr} 4 / 3$ & $\mathrm{Gr} 10 / 3$ \\
$5 \mathrm{~min}$ & $\mathrm{Gr} 0.3 / 5$ & $\mathrm{Gr} 1 / 5$ & $\mathrm{Gr} 4 / 5$ & $\mathrm{Gr} 10 / 5$ \\
\hline
\end{tabular}

Recording of hatching and mortality: During the first week of the experiment, hatching, mortality and abnormal development of the larvae were recorded daily and thereafter every second day until Day 44. Larvae were defined as dead when they had lost their normal transparency and appeared grey, opaque and shrunken. Differences in cumulative mortality were checked for statistical significance by the chi-square contingency table test, assuming a binomial distribution of the data (Zar 1984).

Sampling and tissue preparation. Sampling: All dead and moribund larvae were sampled and subjected to immunohistochemistry or electron microscopy.

Immunohistochemistry: Nodavirus antigens were detected using an avidin-biotin-alkaline-phosphatase complex ( $A B C / A B)$ immunohistochemical technique modified from Hsu et al. (1981) and Evensen (1993). The primary antiserum was raised in rabbit against a recombinant partial coat protein encoded by the T2 region of the RNA2 of the SJNNV (Nishizawa et al. 1994). Fifteen larvae from each group were fixed for $24 \mathrm{~h}$ in neutral phosphate-buffered $10 \%$ formalin, dehydrated through a graded ethanol series and embedded in paraffin. Sections, $3 \mu \mathrm{m}$ thick, were cut on a Reichert-Jung Biocut, dewaxed at 58 to $59^{\circ} \mathrm{C}$ for 30 min, washed in 2 xylene baths, rehydrated through a series of decreasing concentrations of ethanol (100, 96,70 and $50 \%$ ) and brought to distilled water. Nonspecific antibody binding sites were blocked by covering the sections with a solution of $5 \%$ bovine serum albumin (BSA) in Tris-buffered saline (TBS, pH 7.4) for 20 min. The solution was blotted off the slides and the primary rabbit antiserum was incubated at a dilution of $1: 900$ in $2.5 \% \mathrm{BSA}$ in TBS for $30 \mathrm{~min}$. After washing for $5 \mathrm{~min}$ in TBS, the secondary antibody, biotinylated goat anti-rabbit immunoglobulin, diluted $1: 300$ in $2.5 \%$ BSA in TBS (Dakopatts, Glostrup, Denmark), was added and incubated for $30 \mathrm{~min}$. After washing in TBS, streptavidin alkaline phosphatase complex (diluted 1:1000; Boehringer, Darmstadt, Germany) was added and incubated at room temperature for 30 min. After washing, New Fuchsin Chromogen (K698, Dako, California, USA) with $1 \mathrm{mM}$ levamisole (Sigma Co., London, UK) as inhibitor in TBS was added and allowed to develop for $5 \mathrm{~min}$. After a further washing in tap water, sections were counterstained with Mayer's haematoxylin and mounted in an aqueous mounting medium (Aquamount, BDH Laboratory Supplies, UK).

All incubations were performed at room temperature in a humidity chamber. Tissue sections from all viruschallenged and unchallenged groups were incubated with immune and nonimmune serum (normal rabbit serum). The endpoint dilution of the primary antibody that gave an immunolabelling which could be discrim- 
inated from background levels was determined after 30 min incubation at room temperature (Petrusz 1983).

Electron microscopy: For transmission electron microscopy whole larvae were submerged in fixative for at least $24 \mathrm{~h}$. A volume of $100 \mathrm{ml}$ fixative consisted of $10 \mathrm{ml} 10 \%$ formaldehyde (freshly prepared from paraformaldehyde), $10 \mathrm{ml} 25 \%$ glutaraldehyde, $20 \mathrm{ml} 0.2 \mathrm{M}$ cacodylate buffer and $60 \mathrm{ml}$ PBS (pH 7.35). After this primary fixation, the specimens were rinsed in buffer and postfixed in $1 \% \mathrm{OsO}_{4}$, dehydrated in ethanol and embedded in Epon 812 (Fluka Chemie AG, Switzerland). Ultrathin sections were contrasted in uranyl acetate and lead citrate and observed in a JEOL CX 100 transmission electron microscope.

\section{RESULTS}

\section{Hatching}

Delayed hatching or non-hatching was observed in all groups which had been treated with ozonated seawater (Fig. 1). Most of the larvae of the control groups hatched synchronously during a single night (Fig. 1). In the egg groups treated with $4 \mathrm{mg} \mathrm{O}_{3} \mathrm{I}^{-1}$ for $0.5 \mathrm{~min}$ or with lower ozone exposures, hatching was asynchronous, but after $2 \mathrm{~d}$ the cumulative hatching had

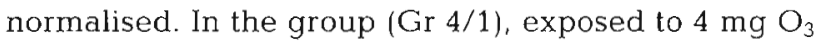
$\mathrm{I}^{-1}$ for $1 \mathrm{~min}$, the hatching rate was $50 \%$, while in the groups treated with $4 \mathrm{mg} \mathrm{O}_{3} \mathrm{l}^{-1}$ for $3 \mathrm{~min}$ or with higher ozone exposures the hatching ranged from 25 to $8 \%$ in a systematic order related to total ozone exposure. When hatching was inhibited, the larvae continued to grow within the eggshell for up to $3 \mathrm{wk}$ and finally died within the egg. The few larvae that hatched in the groups with high ozone exposure developed normally.

\section{Mortality}

The cumulative mortality curves for the different groups are shown in Fig. 2. The groups of eggs treated with $4 \mathrm{mg} \mathrm{O}_{3} \mathrm{l}^{-1}$ for $1 \mathrm{~min}$ or with higher ozone exposures showed the highest cumulative mortalities due to the death of the unhatched larvae. In all these groups cumulative mortalities showed an inverse relationship to hatching rates (Figs. $1 \& 2$ ). However, in these groups with high ozone exposure, the larvae of the few eggs that hatched had high survival rates and showed no signs of abnormal development. The time from the start of the experiment to $50 \%$ cumulative mortality $\left(\mathrm{LT}_{50}\right)$ of these groups varied from 17 to $20 \mathrm{~d}$ and reflected the point of time when the larvae trapped in the egg died.

Low dose ozone disinfection increased the survival rate. The cumulative mortality of the groups treated with $4 \mathrm{mg} \mathrm{O}_{3} \mathrm{I}^{-1}$ for $0.5 \mathrm{~min}$ or with lower ozone exposures ranged between $15 \%(\mathrm{Gr} 4 / 0.5)$ and $40 \%$ ( $\mathrm{Gr}$

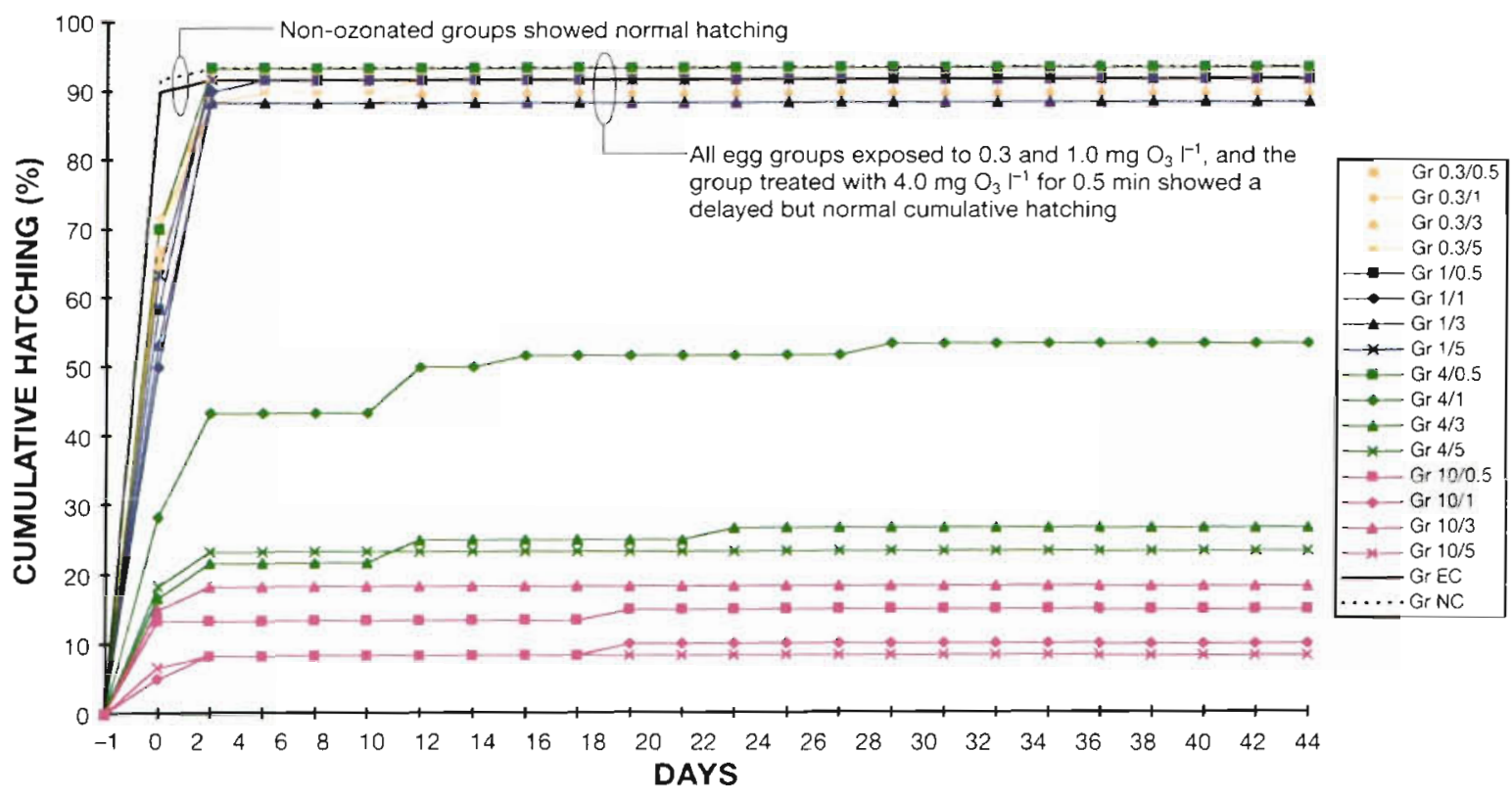

Fig. 1. Hippoglossus hippoglossus. Cumulative hatching in the various groups. The hatching rates of the control groups were normal, reaching above $90 \%$ during 1 night. In the egg groups treated with low ozone exposures (up to and including $4 \mathrm{mg} \mathrm{O}_{3} \mathrm{l}^{-1}$ for $0.5 \mathrm{~min}$ ), the hatching was asynchronous and delayed and reached normal levels after $2 \mathrm{~d}$. In the egg groups receiving high ozone exposures (4 $\mathrm{mg} \mathrm{O}_{3} \mathrm{l}^{-1}$ for $3 \mathrm{~min}$ or higher total exposures), 75 to $92 \%$ did not hatch, but developed inside the eggshell for up to 3 wk before dying. Due to overlap, all curves are not visible. See Table 1 for a description of the experimental groups 


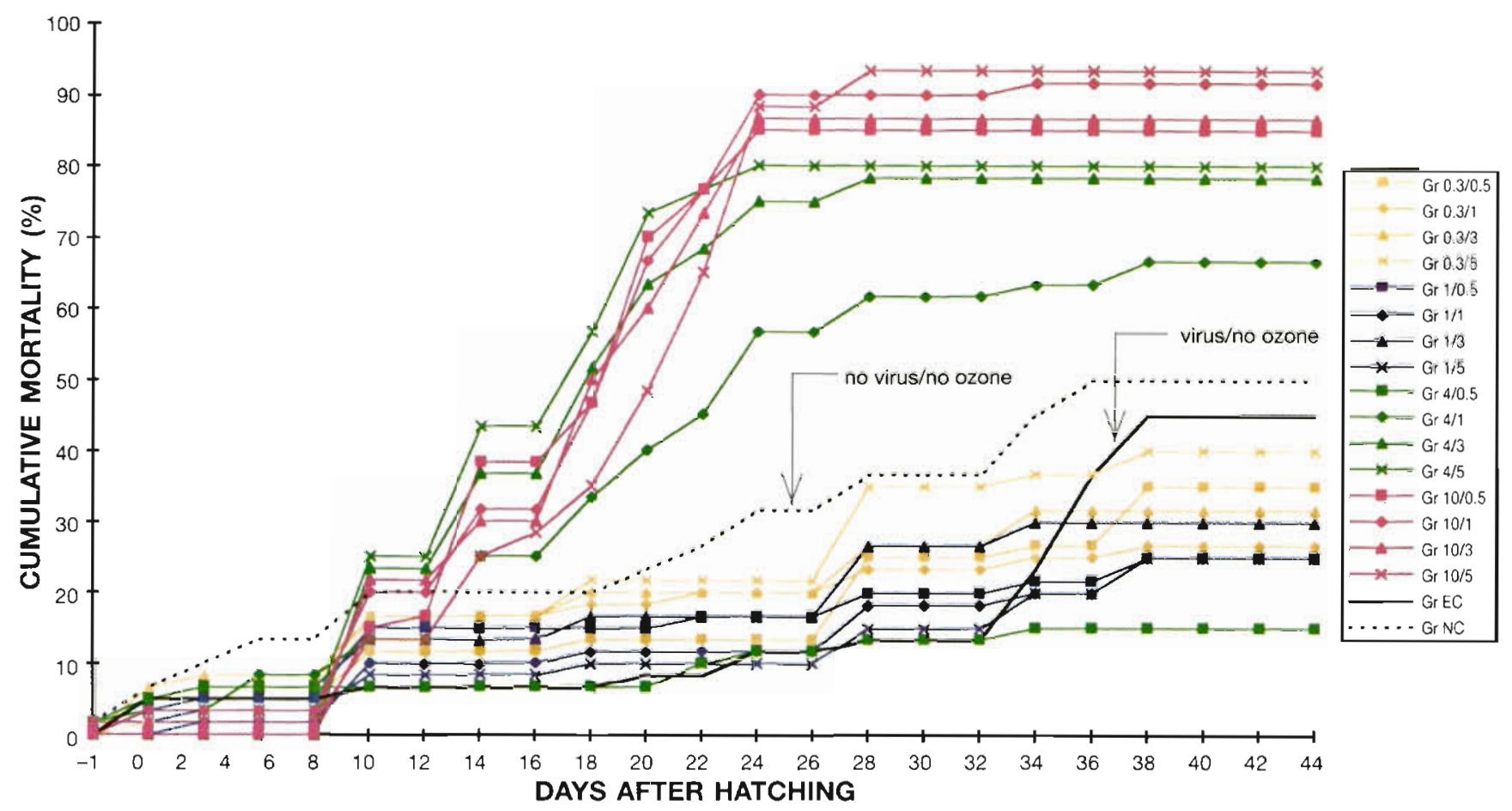

Fig. 2. Hippoglossus hippoglossus. Cumulative mortality in the different groups. Eggs treated with $4 \mathrm{mg} \mathrm{O}_{3} \mathrm{l}^{-1}$ for $0.5 \mathrm{~min}$ or with a lower ozone exposure had higher survival than the eggs of the experimentally virus-exposed control group. The cumulative mortality curves of the groups receiving high ozone exposures ( $4 \mathrm{mg} \mathrm{O}_{3} \mathrm{l}^{-1}$ for $1 \mathrm{~min}$ or higher exposure) follows a steep sigmoid pattern due to the death of unhatched larvae. Note that the cumulative mortality for these groups shows an inverse relation to the hatching rate. See Table 1 for a description of the experimental groups

$0.3 / 5)$. All groups treated with $1 \mathrm{mg} \mathrm{O}_{3} \mathrm{l}^{-1}$ at all 4 exposure times had significantly lower cumulative mortality $(p<0.05)$ compared to the control groups at the termination of the experiment, while among the groups treated with $0.3 \mathrm{mg} \mathrm{O} \mathrm{O}^{-1}$ only the group exposed for $1 \mathrm{~min}$ had a cumulative mortality significantly lower than the controls. The non-treated control group (Gr NC) had a cumulative mortality of $50 \%$, which was not significantly different from the experimentally virusexposed control group (Gr EC) (45\%). The highest survival rate $(85 \%)$ was found in the group exposed to $4 \mathrm{mg} \mathrm{O} \mathrm{O}_{3}^{-1}$ for $0.5 \mathrm{~min}$ and was significantly different from the controls $(p<0.05)$.

\section{Detection of virus}

\section{Immunohistochemistry}

None of the examined larvae exposed to ozonated sea-water (15 from each group) showed any pathological signs of VER and their immunohistochemistry was negative (Fig. 3). Lesions typical of VER concomitant with specific diffuse immunolabelling were detected in the CNS, retina, intestinal anlage, liver anlage, yolksac epithelium, and myotomes in all the 15 larvae examined in the experimentally exposed control group (Gr EC) (Fig. 4). In the non-treated control group (Gr NC) 3 of 15 larvae showed immunolabelling and lesions typical to VER (Fig. 4).

\section{Electron microscopy}

Aggregations of spherical unenveloped virus particles with diameters of approximately $25 \mathrm{~nm}$ were observed in the lesions, and the morphology of the virions was identical to that observed in the infectious material.

\section{DISCUSSION}

VER causes high mortality in reared Atlantic halibut (Grotmol et al. 1997), and a successful hatchery production is dependent on an efficient control of this infection. In the present study 2 lines of evidence indicates that nodavirus are inactivated by ozonated seawater. First, the survival rate of the 4 groups exposed to $1 \mathrm{mg} \mathrm{O}_{3} \mathrm{I}^{-1}$ and the group exposed to $4 \mathrm{mg} \mathrm{O} \mathrm{O}^{-1}$ for $0.5 \mathrm{~min}$ were significantly higher than in the control groups. Furthermore, nodavirus infection was not de- 

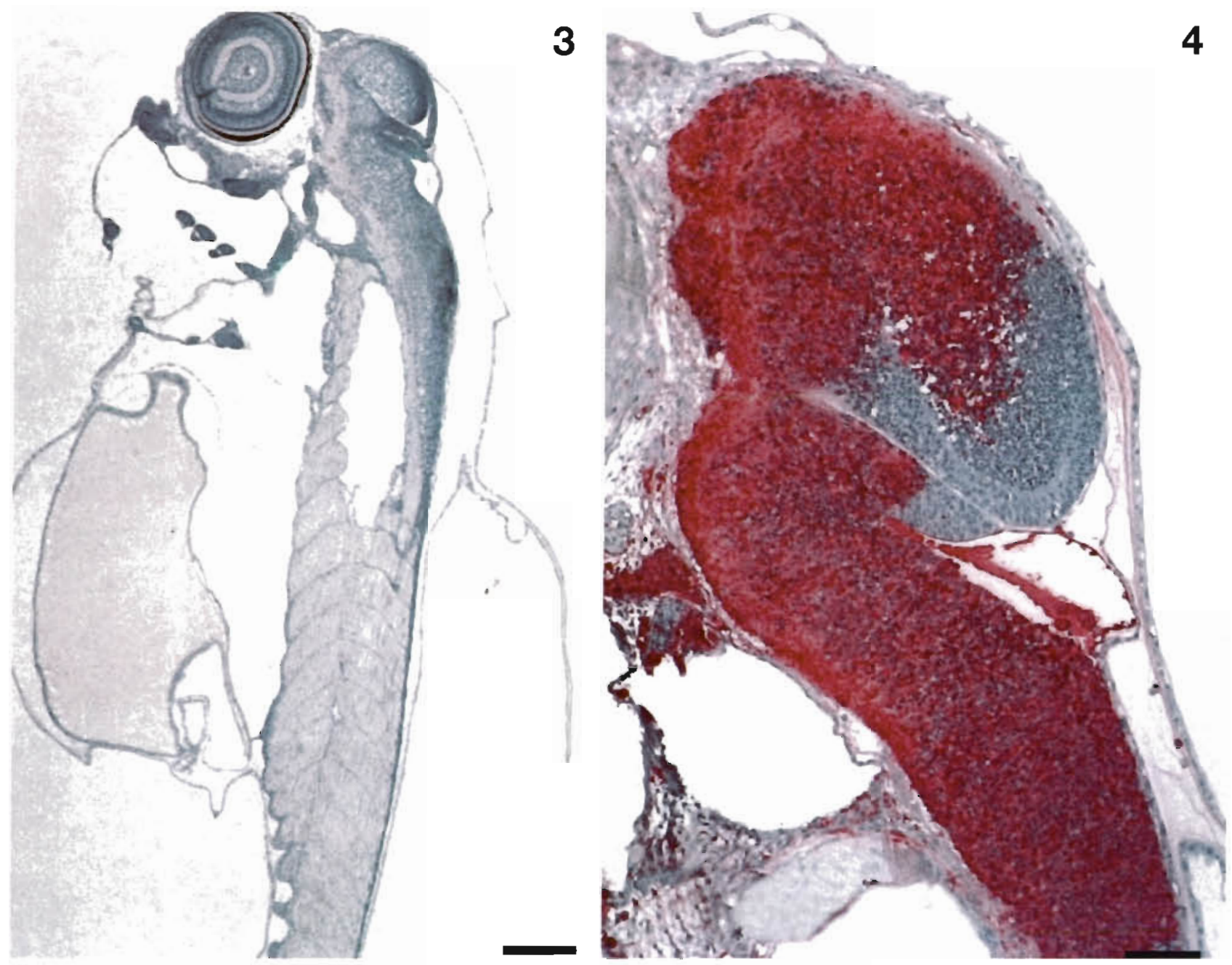

Figs. 3 \& 4 . Hippoglossus hippoglossus yolk-sac larvae. Immunohistochemical staining of paraffin sections. Avidin biotin alkaline phosphatase method, rabbit antiserum against a recombinant partial coat protein of SJNNV and Mayers Haematoxylin counterstain. Fig. 3. Larva from a group of eggs disinfected with ozonated sea-water (Gr 1/5) $30 \mathrm{~d}$ after hatching. Note the absence of immunolabelling. Scale bar $=50 \mu \mathrm{m}$. Fig. 4. Brain of larva from the experimentally virus-exposed control group (Gr EC) on Day 30 showing diffuse immunolabelling. Scale bar $=10 \mu \mathrm{m}$

tected in any larvae from eggs treated with ozone. In contrast, nodavirus were detected in a high number of larvae of the control groups. Nodaviruses are among the most stable fish pathogens, being resistant to $\mathrm{pH}$ $2-9$, heating at $56^{\circ} \mathrm{C}$ for 30 min (Frerichs et al 1996) and retaining their infectivity after storage in seawater for more than a year at $15^{\circ} \mathrm{C}$ (Frerichs \& Tweedie 1997). Previous studies have shown that iodine and formaldehyde do not reduce sufficiently the viability of nodavirus (SJNNV) associated with eggs from striped jack, but demonstrated that ozonated sea-water had a potent nodavirucidal effect (Arimoto et al. 1996). In comparison with eggs of the striped jack. Atlantic halibut eggs tolerated considerably higher exposure to ozone with no adverse toxic or teratogenic effects on the yolk-sac larvae in the observation period here. This broad ozone tolerance may be exploited to reduce the risk of nodavirus infection in halibut larvae.

In the present study, larvae in the experimentally virus-exposed (Gr EC) and in the non-virus exposed (Gr NC) control groups were infected with nodavirus and at the termination of the experiment the cumulative mortality of these 2 groups were similar, approximately $50 \%$. In our previous report, when hatched larvae were exposed to the same infectious material (Grotmol et al. 1999) the cumulative mortality was $100 \%$ in all challenged groups. The significantly lower cumulative mortality of the control groups of the present study may result from a much lower concentration of nodavirus in the exposure dose. Furthermore, after virus exposure the eggs were strained and then resuspended 2 times in autoclaved sea-water and there- 
after individually transferred to wells, where most of the water was changed after hatching. This procedure results in a considerable dilution of the nodavirus. The variation in cumulative mortality between the groups with low ozone exposure is difficult to evaluate since nodavirus was not detected in any of these groups

The major routes for transmission of nodavirus are horizontally through sea-water (Arimoto et al. 1993, 1994) and vertically from broodstock to offspring through the gonadal fluids (Arimoto et al. 1992, Mushiake et al. 1994, Yoshimizu et al. 1997). With vertical transmission, the nodavirus particles are thought to adhere to the surface of the egg (Arimoto et al. 1996). In the case of the Atlantic halibut, it has not been possible to detect nodavirus in gonadal fluids by means of RT-PCR (Grotmol unpubl, data). The presence of VER in the non-treated control group of the present study, however, indicates that virus was associated with the eggs, possibly in amounts below detection limit of the employed RT-PCR method. Alternatively, the virus may have originated from the sea-water and infected the eggs during storage in the upwelling incubator in the hatchery. A third possibility is that nodavirus was present in the embryo within the egg, but the lack of immunolabelling in the larvae after treatment with ozonated sea-water makes it more probable that the nodavirus was present only on the egg surface. Detection of nodavirus in the non-treated control group indicates that nodavirus associated with eggs may play a role in the epidemiology of VER in the Atlantic halibut.

The mechanism of nodavirus inactivation by ozonated sea-water is not known. A study on poliovirus (Roy et al. 1981) showed that ozone had effects on both the coat protein and the RNA genome. It was concluded that the major virucidal effect was caused by damage to the viral nucleic acid. The adverse effect of high ozone exposures on hatching in our study may be due to modification of the eggshell protein polymer by the oxidants, rendering it resistant to the hatching enzyme. Alternatively, the secretion of enzyme from the hatching gland may have been inhibited. When disinfecting fish eggs of other species with ozonated sea-water, similar side effects on hatchability have been observed (Hall et al. 1981, Arimoto et al. 1996, Mimura et al. 1998). This negative effect of excess oxidants necessitates following a strict protocol and maintaining close surveillance of the concentration of ozone employed in large-scale disinfection of eggs.

In the laboratory scale model employed in our study, each well is an independent experimental unit for the rearing and monitoring of individual eggs or larvae. The inherent advantages of this model make it a precise tool for the study of the effects of disinfectants and pathogens on eggs and larvae. Although our procedure for egg disinfection has not been tested in indus- trial production, the method may be scaled up and implemented in the current production methods for Atlantic halibut.

Acknowledgements. The authors thank Gen Mimura for valuable methodological suggestions to the study. Dr Eirik Biering is thanked for producing the antiserum. Pål Kristiansen and Dagfinn Oterhals from PK Ozone AS (Molde, Norway) are thanked for supplying the ozone generator and for technical assistance. Ingrid Uglenes, Tove Boge Eriksen and Teresa Cieplinska are also thanked for their excellent technical assistance.

\section{LITERATURE CITED}

Arimoto M, Mushiake K, Mizuta Y, Nakai T, Muroga K, Furusawa I (1992) Detection of striped jack nervous necrosis virus ( $S J N N V$ ) from striped jack by enzyme-linked immunosorbent assay (ELISA). Gyobyo Kenkyu 27:191-195

Arimoto M, Mori K, Nakai T, Muroga K, Furusawa I (1993) Pathogenicity of the causative agent of viral nervous necrosis disease in striped jack, Pseudocaranx dentex (Block and Sneider). J Fish Dis 16:461-469

Arimoto M, Maruyama K, Furusawa I (1994) Epizootiology of viral nervous necrosis (VNN) in striped jack. Gyobyo Kenkyu 29(1):19-24 (in Japanese)

Arimoto M, Sato J, Maruyama K, Mimura G, Furusawa I (1996) Effect of chemical and physical treatments on the inactivation of striped jack nervous necrosis virus (SJNNV). Aquaculture 143:15-22

Bergh $\varnothing$, Jelmert A (1996) Jodophor disinfection of eggs of Atlantic halibut. J Aquat Anim Health 8:135-145

Breuil G, Bonami JF, Pichot Y (1991) Viral infection (picornalike virus) associated with mass mortalities in hatcheryreared sea-bass (Dicentrarchus labrax) larvae and juveniles. Aquaculture 97:109-116

Comps M, Pepin JF, Bonami JR (1994) Purification and characterisation of two fish encephalitis virus (FEV) infecting Lates calcarifer and Dicentrarchus labrax. Aquaculture 123:1-10

Comps M, Trindade, M, Delsert V (1996) Investigation of fish encephalitis viruses expression in marine fishes using DIGlabelled probes. Aquaculture 143:113-121

Evensen $\varnothing$ (1993) An immunohistochemical study on the cytogenetic origin of pulmonary multinucleate giant cells in porcine dermatosis vegitans. Vet Pathol 31:162-170

Franson MAH (ed) (1989) Standard methods for the examination of water and wastewater, 17 th edn. Chap. 4. American Public Health Association, Washington, DC, p 48-51

Frerichs GN Tweedie A (1997) Survival and inactivation of piscine neuropathy nodavirus. In: VIIIth International Conference on 'Diseases of Fish and Shellfish' Edinburgh, p 97, ISBN 0-95-262424-9

Frerichs GN, Roger HD, Peric Z (1996) Cell culture isolation of piscine neuropathy nodavirus from juvenile sea bass, Dicentrachus labrax. J Gen Virol 77:2067-2071

Grotmol S, Totland GK, Thorud K, Hjeltnes BK (1997) Vacuolating encephalopathy and retinopathy associated with a nodavirus-like agent: a probable cause of mass mortality of cultured larval and juvenile Atlantic halibut Hippoglossus hippoglossus. Dis Aquat Org 29:85-97

Grotmol S, Bergh $\varnothing$, Totland GK (1999) Transmission of viral encephalopathy and retinopathy (VER) to yolk-sac larvae of the Atlantic halibut Hippoglossus hippoglossus: occurrence of nodavirus in various organs and a possible route of infection. Dis Aquat Org 36:95-106 
Hall L, Sato J, Maruyama K, Mimura G, Furuzawa I (1981) Comparison of ozone and chlorine toxicity to the developmental stages of striped bass, Morone saxatilis. Can J Fish Aquat Sci 38:752-757

Harboe T, Huse I, Øie G (1994) Effects of egg disinfection on yolk sac and first feeding stages of halibut (Hippoglossus hippoglossus L.) larvae. Aquaculture 119:157-165

Hsu SM, Raine L, Fanger H (1981) Use of an avidin-biotinperoxidase complex $(A B C)$ in immunoperoxidase techniques: a comparison between $\mathrm{ABC}$ and unlabelled antibody (PAP) procedures. J Histochem Cytochem 29: $577-580$

Mimura G, Nagase T, Katayama Y, Nagamitu, T, Namba K (1998) Effect of ozone-produced oxidants on eggs of Japanese flounder, Paralichthys olivaceus. Fish Pathol 46(1):101-110 (in Japanese)

Mori K, Nakai T, Muroga K, Arimoto M, Mushiake K, Furusawa I (1992) Properties of a new virus belonging to Nodaviridae found in larval striped jack (Pseudocaranx dentex) with nervous necrosis. Virology 187:368-371

Munday BL, Nakai T (1997) Special topic review: nodaviruses as pathogens in larval and juvenile marine finfish. World J Microbiol Biotechnol 13:375-381

Munday BL, Langdon JS, Hyatt A, Humphrey JD (1992) Mass mortality associated with a viral-induced vacuolating encephalopathy and retinopathy of larval and juvenile barramundi, Lates calcarifer Bloch. Aquaculture 103:197-211

Mushiake K, Nishizawa T, Nakai T, Furusawa I, Muroga K (1994) Control of VNN in striped jack. Selection of spawners based on the detection of SJNNV gene by polymerase chain reaction (PCR). Fish Pathol 29:177-182

Nishizawa T, Mori K, Nakai T, Furusawa I, Muroga K (1994) Polymerase chain reaction (PCR) amplification of RNA of striped jack nervous necrosis virus (SJNNV). Dis Aquat Org 18:103-107

Nishizawa T, Muroga K, Arimoto M (1996) Failure of the poly-

Editorial responsibility: Jo-Ann Leong,

Corvallis, Oregon, USA merase chain reaction ( $\mathrm{PCR}$ ) method to detect striped jack nervous necrosis virus (SJNNV) in striped jack Pseudocaranx dentex selected as spawners. J Aquat Anim Health 8:332-334

Petrusz P (1983) Essential requirements for the validity of immunocytochemical staining procedures. J Histochem Cytochem 31:177-179

Pittman K, Skiftesvik AB, Berg L (1990) Morphological and behavioural development of halibut Hippoglossus hippoglossus L. larvae. J Fish Biol 37:455-472

Roy D, Wong PK, Engelbrecht RS, Chian ES (1981) Mechanism of enteroviral inactivation by ozone. Appl Environ Microbiol 41(3):718-723

Salvesen I, Vadstein O (1995) Surface disinfection of eggs from marine fish: evaluation of four chemicals. Aquacult Int 3:155-171

Song ZR, Kanai $K$, Yoshikoshi $K$, Niiyama $H$, Honda A, Ura $K$ (1997) Mass mortalities of hatchery-reared larvae and juveniles of bartail flathead, Platycephalus indicus associated with viral nervous necrosis. Suisanzoshoku 45(2): $241-246$

Yoshikoshi K, Inuoe K (1990) Viral nervous necrosis in hatchery-reared larvae and juveniles of Japanese parrot-fish, Oplegnathus fasciatus (Temminck \& Schlegel). J Fish Dis 13:69-77

Yoshimizu M, Hyuga S, Oh MJ, Ezura Y, Ito S, Minura G (1995) Disinfectant effect of oxidant produced by ozonization of sea water on fish pathogenic viruses, bacteria, and ciliata. Dis Asian Aquacult 11:203-209

Yoshimizu M, Suzuki K, Nishizawa T, Winton JR, Ezura Y (1997) Antibody screening for the identification of nervous necrosis virus carriers in a flounder brood stock. In: Proc NRIA International Workshop 'New Approaches to Viral Diseases of Aquatic Animals'. Kyoto, p 124-130

Zar JH (1984) Biostatistical analysis, 2nd edn. Prentice-Hall Inc, Engelwood Cliffs, NJ

Submitted: April 12, 1999; Accepted: November 10, 1999 Proofs received from author(s): January 3, 2000 